ISBN 978-81-933894-1-6

2017 International Conference on Studies in Business Management, Law and Education

(SBMLE-17)

Kyoto (Japan) April 20-21, 2017

\title{
Innovation, Industry Competition and Corporate Performance
}

\author{
Pei-shan, Lu ${ }^{1}$, Cian-Yu, Chen ${ }^{1 *}$ \\ ${ }^{1}$ Chaoyang University of Technology/ Department of Accounting \\ s10424608@gm ail.com
}

\begin{abstract}
The aim of this study was to investigate how corporate performance was related to innovation as well as how the relationship was mediated by industry competition. Over the past few years, innovation have received much attention since innovation is one of key factors in the competitive power and the success of firms. The extant studies used $R \& D$ expenditures as a proxy for the level of innovation to examine how innovation affected firms' performance. However, empirical research on the relationship between innovation and corporate performance has reached controversial conclusions. Practically, not all of $R \& D$ expenditures of firms could be "successful " $R \& D$ " lead to high performance; nevertheless, most of firms devote in innovation and $R \& D$ continuously. Industry competition, might explain why firms constantly invest in innovation, whether these projects succeed or not. Using data belonging to electronics industry between 2000 and 2015 retrieved from Taiwan Economic Journal Database, the empirical findings showed positive effect of "speed of innovation" but negative effect of " $R \& D$ intensity" and " $R \& D$ density" on business performance. Moreover, we found that the effect of "speed of innovation" on business performance became stronger if business faced much more competition. This study supported the role of industry competition in innovation as well as reinforced the understanding of innovation and performance.
\end{abstract}

Keywords: innovation, industry competition, corporate performance

\section{Introduction}

Innovation leads business not only to increase competitiveness in industry but also to create profitability and economic value. The impact of innovation on financial performance was supported (Hult, Hurley, \& Knight, 2004). Nevertheless, the relationship between innovation and financial performance have reached incongruent conclusions, some empirical studies suggest that innovation may not reward financial performance or may cause negative performance (e.g. Heunks, 1998; Vermeulen et al., 2005; Terziovski, 2010). Meanwhile, many studies have shown evidence of positive effects (e.g. Anderson et al., 2014; Schulz \& Jobe, 2001).

Taiwan companies, the top four ranking in the number of patents granted in United States Patent and Trademark Office (USPTO) in 2015, invested much efforts in innovation or patent. The record showed that firms devoted much in innovation and Research \& Development (R\&D); however, the contribution of innovation to profit is not always clear. Industry competition, such as electronics industry under the circumstances of high global competitiveness, might explain why firms constantly invest in innovation, whether these projects succeed or not. Steady innovation is possible key strategies of firms to face the challenge from competitors as well as remain business competitiveness (e.g. Helms et al., 1997; Christensen, 1997). Therefore, this study retrieved data belonging to electronics between 2000 and 2015 retrieved from Taiwan Economic Journal Database to examine how financial performance was related to innovation as well as how the relationship was mediated by industry competition. 


\section{Theoretical Background and Hypotheses Development}

Innovation is a key factors for firms to enhance the competitive power and reach in success. Innovation is a process of developing new products in business (Tushman \& Nadler, 1986). Firms continuously invest in innovation would get be growing faster than firms did not (Chainelli et al., 2004). However, empirical studies have showed controversial results which innovation might positive, negative or no relation with corporate performance (e.g. Anderson et al., 2014; Heunks, 1998; Terziovski, 2010; Schulz \& Jobe, 2001; Vermeulen et al., 2005). Using single index, such as percentage of $R \& D$ investment over revenue, to measure the level innovation may cause these mixed findings. In this study, we followed Huang \& Lin (2016) and adopted R\&D density, R\&D intensity and speed of innovation to capture the level of innovation.

Cohen \& Levinthal (1990) and Lev \& Sougiannis (1996) suggested the positive relationship between innovation and $R \& D$ density measured by percentage of $R \& D$ investment over revenue. Thus we hypothesize a positive relationship between R\&D density. Lin, Lee \& Hung (2006) used R\&D intensity, R\&D expenditure divided by book value of total assets, to capture how firms utilize assets in innovation. High R\&D intensity may possibly lead firms to achieve a premium for innovative products in order to cope with competitive market and technology innovation. Kessler \& Chakrabarti (1996) suggested that speed of innovation could short spending and timing of new product development. According to Garner Nam \& Ottoo (2002), speed of innovation is related to market value based on how long firms take to launch a new product. Therefore, our model suggest a positive effect of innovation, including $R \& D$ density, $R \& D$ intensity and the speed of innovation, on financial performance. Meanwhile, performance of innovation can be influenced by firm size (Huang, 2007), leverage (Nogaoka, 2007) and firm age (Huang \& Lin, 2016). We follow the literature and control these variables in our models. We make the following hypotheses :

Hypothesis 1a: R\&D density has a positive impact on financial performance.

Hypothesis 1b: R\&D intensity has a positive impact on financial performance.

Hypothesis 1c: Speed of innovation has a positive impact on financial performance.

In a highly competitive environment, enterprises must continue to develop new technologies or new products to keep their advantage position in such an environment (Allen \& Gale, 2000). Moreover, enterprises will enhance market value contributed by unique competencies of innovation related to continuous investment (Hill and Jones, 2004). Therefore, this study explores whether industry competition impacts innovation effect. Therefore, we propose the following hypothesis:

Hypothesis 2: Industry competition moderates the relationship between innovation and performance that relationship is stronger in firms with a high competitive market.

\section{Methodology and Model}

\subsection{Sample Construction}

This research employed data items such as ROA, R\&D expense, total assets and industry financial data from the Taiwan Economic Journal Database (TEJ) for the 16 years from the year 2000 to 2015. We selected the firms operating in electronics industry using two-digit industry code. Table 1 shows the subgroup levels of electronics industries which we selected.

TABLE I: Subgroups of Electronics Industries

\begin{tabular}{llr}
\hline \hline TSE & electronics industry & Number \\
\hline 24 & Semiconductor industry & 68 \\
25 & Computer and peripheral equipment industry & 61 \\
26 & Optoelectronics industry & 47 \\
27 & Communication network industry & 39 \\
28 & Electronic Components Industry & 110 \\
29 & Electronic access industry & 18 \\
30 & Information Services & 22 \\
31 & Other electronics industry & 34 \\
\hline \hline
\end{tabular}




\subsection{Variables definitions and methodology}

Our regression model measured performance of innovation, while controlling for firm size, leverage and years of firm having been formed. The model also examined the conditional effects of industry competition and mediation effects of industry competition. The following is the regression model:

$$
\mathrm{ROA}_{i t}=\beta_{0}+\beta_{1} \mathrm{RDD}_{i t}+\beta_{2} \mathrm{RDI}_{i t}+\beta_{3} \mathrm{SI}_{i t}+\beta_{4} \mathrm{HHI}_{i t}+\beta_{5} \mathrm{PI}_{i t}+\beta_{6} \mathrm{HHI}_{i t} \times \mathrm{SI}_{i t}+\beta_{7} \mathrm{SIZE}_{i t}+\beta_{8} \mathrm{LEV}+\beta_{9} \mathrm{AGE}_{i t}+\varepsilon
$$

where for firm $\mathrm{i}$ in year $\mathrm{t}: \mathrm{ROA}_{i t}=($ Net profit + net interest expense after tax $) /$ average total assets; $\mathrm{RDD}_{i t}=$ $\mathrm{R} \& \mathrm{D}$ density ( $\mathrm{R} \& \mathrm{D}$ expenditure/net sales); $\mathrm{RDI}_{i t}=\mathrm{R} \& \mathrm{D}$ intensity ( $\mathrm{R} \& \mathrm{D}$ expenditure/ book value of total assets); $\mathrm{SI}_{i t}=$ Speed of innovation ( $\mathrm{R} \& \mathrm{D}$ expenditure of subgroup industry which firm $\mathrm{i}$ attributed/ book value of total assets) / (average R\&D expenditure of subgroup industry which firm i attributed/ average total assets of subgroup industry which firm in attributed $)$; $\mathrm{HHI}_{i t}=$ Industry competition ( $1=$ competition market, $0=$ monopoly market, classified based on Herfindahl-Hirschman Index); $\mathrm{PI}_{i t}=$ volatility of industry profit (standard deviation of net income in subgroup industries / average net revenue of subgroup industries); $\mathrm{SIZE}_{i t}=$ size of company (the natural logarithm of total assets); $\mathrm{LEV}=$ debt ratio (total liabilities / total assets); $\mathrm{AGE}_{i t}=$ firm age).

\section{Results}

\subsection{Descriptive Statistics}

Our samples were selected from electronics firms. We identified 6,382 firm year observations of firms with complete financial data in the 2000 to 2015 . Table II shows the summary statistics for firm-level ROA, R\&D density, R\&D intensive, speed of innovation, and firm characteristics.

Table III reports the correlation matrix. We can see that ROA is negatively related to R\&D density (RDD), R\&D intensive (RDI) and speed of innovation (SI), and positively related to industry competition (HHI) and volatility of industry profit (PI). The correlation between RDI and SI is higher. Therefore, we did VIF collinearity test that VIF values, range from 1.011 to 3.429 , showed no collinearity among variables.

TABLE II: Narrative Statistics is

\begin{tabular}{lcc}
\hline \hline variable & Mean & Std. Deviation \\
\hline ROA & 0.0503 & 0.010457 \\
RDD & 0.06522 & 0.865880 \\
RDI & 0.03528 & 0.043051 \\
SI & 1.4305 & 1.519660 \\
HHI & 0.42 & 0.493000 \\
PI & 2.93966 & 1.173520 \\
HHIxSI & 1.18567 & 0.996960 \\
SIZE & 22.16458 & 1.500210 \\
LEV & 40.5443 & 17.136020 \\
AGE & 14.97 & 3.317000 \\
\hline \hline
\end{tabular}


TABLE III: Pearson

\begin{tabular}{|c|c|c|c|c|c|c|c|c|c|c|}
\hline variable & ROA & RDD & RDI & SI & HHI & PI & HHIxSI & SIZE & LEV & AGE \\
\hline ROA & 1 & $-0.051^{*}$ & $-0.052^{*}$ & $-0.001^{* * * *}$ & $-0.046^{* *}$ & $0.052^{*}$ & $0.039^{* *}$ & 0.123 & -0.233 & $-0.078^{*}$ \\
\hline RDD & & 1 & $0.077^{*}$ & $0.077^{*}$ & -0.13 & $-0.04^{* *}$ & $0.092^{*}$ & $0.057^{*}$ & $0.032^{* *}$ & $-0.016^{*}$ \\
\hline RDI & & & 1 & $0.796^{*}$ & $0.04^{*}$ & $0.04^{* *}$ & 0.685 & -0.157 & -0.285 & $-0.069^{*}$ \\
\hline SI & & & & 1 & 0.124 & $0.006^{* * * *}$ & 0.623 & -0.185 & -0.186 & $-0.090^{*}$ \\
\hline HHI & & & & & 1 & -0.378 & -0.159 & -0.110 & $-0.060^{*}$ & $0.003^{* * *}$ \\
\hline PI & & & & & & 1 & $-0.015^{* *}$ & $0.060^{*}$ & $-0.056^{*}$ & $0.057^{*}$ \\
\hline HHIxSI & & & & & & & 1 & -0.170 & -0.191 & $-0.089^{*}$ \\
\hline SIZE & & & & & & & & 1 & 0.219 & 0.418 \\
\hline LEV & & & & & & & & & 1 & $0.053^{*}$ \\
\hline AGE & & & & & & & & & & 1 \\
\hline
\end{tabular}

Note: $* * * * *, *$ were $1 \%, 5 \%$ and $10 \%$ significant level.

\subsection{Regression Analysis}

In order to examine the performance of innovation, we use multiple regression to test our hypotheses. Table IV shows the multiple regression results. According to the results, firm size (SIZE) is positively related to firm performance, while the debt ratio (LEV) and firm age (AGE) are significantly negative related to firm performance.

TABLE IV: Results of Regression Analysis

$\mathrm{ROA}_{i t}=\beta_{0}+\beta_{1} \mathrm{RDD}_{i t}+\beta_{2} \mathrm{RDI}_{i t}+\beta_{3} \mathrm{SI}_{i t}+\beta_{4} \mathrm{HHI}_{i t}+\beta_{5} \mathrm{PI}_{i t}+\beta_{6} \mathrm{HHI}_{i t} \times \mathrm{SI}_{i t}+\beta_{7} \mathrm{SIZE}_{i t}+\beta_{8} \mathrm{LEV}+\beta_{9} \mathrm{AGE}_{i t}+\varepsilon$

\begin{tabular}{|c|c|c|c|c|c|c|}
\hline \multirow{2}{*}{ variable } & \multicolumn{2}{|c|}{ Model1 } & \multicolumn{2}{|c|}{ Model2 } & \multicolumn{2}{|c|}{ Model3 } \\
\hline & coefficient & T-value & coefficient & T-value & coefficient & T-value \\
\hline SIZE & $\begin{array}{c}1.776 \\
(0.000)^{* * *}\end{array}$ & 19.131 & $\begin{array}{c}1.842 \\
(0.000)^{\text {*** }}\end{array}$ & 7.028 & $\begin{array}{c}1.852 \\
(0.000)^{* * *}\end{array}$ & 6.976 \\
\hline LEV & $\begin{array}{c}-0.170 \\
(0.000)^{* * * *}\end{array}$ & -23.046 & $\begin{array}{c}-0.190 \\
(0.000)^{* * * *}\end{array}$ & -14.910 & $\begin{array}{c}-0.191 \\
(0.000)^{* * *}\end{array}$ & -14.911 \\
\hline AGE & $\begin{array}{c}-0.535 \\
(0.000)^{* * *}\end{array}$ & -13.029 & $\begin{array}{c}-0.558 \\
(0.000)^{* * *}\end{array}$ & -4.397 & $\begin{array}{c}-0.546 \\
(0.000)^{* * *}\end{array}$ & -4.262 \\
\hline RDD & & & $\begin{array}{c}-0542 \\
(0.000)^{* * * *}\end{array}$ & -3.857 & $\begin{array}{c}-0.587 \\
(0.000)^{* * * *}\end{array}$ & -11.082 \\
\hline RDI & & & $\begin{array}{l}-66.193 \\
(0.000)^{\text {**** }}\end{array}$ & -13.709 & $\begin{array}{c}-79.841 \\
(0.000)^{* * *}\end{array}$ & 6.263 \\
\hline SI & & & $\begin{array}{c}1.433 \\
(0.000)^{\text {*** }}\end{array}$ & 10.540 & $\begin{array}{c}1.215 \\
(0.000)^{* * *}\end{array}$ & 1.222 \\
\hline PI & & & $\begin{array}{c}0.704 \\
(0.000)^{\text {**** }}\end{array}$ & 6.223 & $\begin{array}{c}0.641 \\
(0.000)^{\text {*** }}\end{array}$ & 5.677 \\
\hline HHI & & & $\begin{array}{c}-2.151 \\
(0.000)^{* * *}\end{array}$ & -7.864 & $\begin{array}{c}-1.569 \\
(0.000)^{* * *}\end{array}$ & .715 \\
\hline HHIxSI & & & & & $\begin{array}{c}1.242 \\
(0.000)^{* * *}\end{array}$ & 6.967 \\
\hline
\end{tabular}

註: ***,**, * were $1 \%, 5 \%$ and $10 \%$ significant level。 
In Model 2, R\&D density (RDD) and R\&D intensity (RDI) carries a positive and significant coefficient, which does not support our hypothesis $1 \mathrm{a}$ and hypothesis $1 \mathrm{~b}$.The result is similar to previous literatures in terms of negative effects of innovation on ROA. On the other hand, the finding in Model 2 suggests that firms have increasing ROA since they have high speedy on innovation (SI). The result supports hypothesis $1 \mathrm{c}$ as well. The positive relationship shows that faster of speed of innovation is, the more return of business performance will be rewarded. Finally, the model 3 includes interaction term of industry competition (HHI) and speed of innovation (SI). The result shows that firms with high speedy of innovation with a positive relationship with ROA. Moreover, hypothesis 2 is supported by that the interaction term of SI and HHI has a positive relationship with ROA. Industry competition moderates the relationship between innovation and performance that relationship is stronger in firms with a high competitive market.

\section{Conclusion}

Innovation is one of key factor for business not only to maintain firm competition but also to enhance firm and industry value. Our results show that innovation and industry competition are related to financial performance. The more $R \& D$ density and $R \& D$ intensity firms have, the less return of assets firms earn. It appears that firms invested much $\mathrm{R} \& \mathrm{D}$ expenditures lead to negative effects on business performance. Nevertheless, firms with higher speedy of innovation earn higher return of assets. Finally, this paper investigates how industry competition mediates the relationship between innovation of enterprises and business performance. Our findings show that mediating effect exists and that in a high degree of industrial creconompetition if the increase in the speed of innovation will increase its business performance.

\section{Reference}

[1] Allen, F. and Gale, D. "Corporate governance and competition." Corporate Governance-Theoretical and Empirical Perspectives, edited by Xavier Vives, 2000.

https://doi.org/10.1017/CBO9781139175333.003

[2] Anderson, N., Potocnik, k. and Zhou, J, "Innovation and creativity in organizations: a state-of-the-science review, prospective commentary, and guiding framework," Journal of Management, Vol.40, pp.1297-1333, 2014.

https://doi.org/10.1177/0149206314527128

[3] Cheng-Jen Huang, and Ping-Hsiao Lin, "The Structural Analysis of Value Creation for Innovation: Evidence from Taiwan's Electronics Industry,” Journal of Accounting Review, vol.62, pp.1-32, Jan 2016.

[4] Christensen, C., "The Innovator's Dilemma: When New Technologies cause Great Firms to Fail”, Harvard Business School Press, Cambridge, M A, 1997.

[5] Cohen, Wesley M. and Daniel, A. Levinthal, "Absorptive Capacity: A New perspective on Learning and Innovation." Administrative Science Quarterly, vol. 35, pp.197-218, 1990.1

[6] Garner, J. Nam L., J. and Ottoo R. E., "Enterminants of Corporate Growth Opportunities of Emerging Firm?", Journal of Economics and Business, vol.54, pp.73-93, 2002.

https://doi.org/10.1016/S0148-6195(01)00056-X

[7] Helms, M. M., Dibrell, C. and Wright, P. "Competitive Strategies and Business Performance: Evidence from the Adhesives and Sealants Industry,” Management Decision, vol.35. no.9, pp.678-692, 1997

https://doi.org/10.1108/00251749710186531.

[8] Heunks, J,“Innovation, Creativity and Success”, Journal of Small Business Economics, vol.10, pp.263-272, 1998. https://doi.org/10.1023/A:1007968217565

[9] Hill, C. W. L., and Jones, "Strategy Management Theory: an integrated approach," Hard Bound In: English Deep \& Deep Publication, vol.6, 2004.

[10] Huang, C. J.“The determinants and performance of R\&D cooperation Evidence from Taiwan's high-technology industries," Ph.D dissertation, Department of Accounting, National Chengchi University, Taipei, Taiwan, 2007.

[11] Hult, G. T. M., Hurley, R. F., and Knight, G. A., "Innovativeness: Its antecedents and impact on business performance." Industrial Marketing Management, vol.33, pp.429-438, 2004.

https://doi.org/10.1016/j.indmarman.2003.08.015 
[12] Kessler, E. H. and Chakrabarti, A. K. "Innovation speed: A conceptual model of context, antecedents and outcomes" Academy of Management Review, vol. 21, pp.1143-1191, 1996.

[13] Lev, B. Sougiannis, T."The Capitalization, arnortization, and value-relevance of R\&D”, Journal of Accounting and Economics, vol.21, pp.107-138, 1996. https://doi.org/10.1016/0165-4101(95)00410-6

[14] Nagaoka, S. "Assessing the R\&D Management of a Firm in Terms of Speed and Science Linkage: Evidence from the US Patents." Journal of Economics \& Management Strategy, Vol.16, pp.129-157, 2007.

[15] Schulz, M. and Jobe, L. A."Codification and Tacitness as Knowledge management strategies: An empirical exploration,” Journal of high Technology Management Research, vol.12, pp.139-165, 2001.

https://doi.org/10.1016/S1047-8310(00)00043-2

[16] Terziovski."Innovation and its Performance Implication in Small and Medium Entreprices in Manufacturing Sector: A resource based view," Strategic Management Journal, vol.31, pp. 892-902, 2010.

[17] Tushman, M. and Nadler, D. “Orgenizing for innovation.” California Management Review, vol.28, pp.74-92, 1986. https://doi.org/10.2307/41165203

[18] Vermeulen, P. A. M., De Jong JPJ., O'shaughnessy, "identifying, key determinants for new product introductions and firm performance in small service firms" Service Industry Jounal, vol.25, pp.625-640, 2005.

https://doi.org/10.1080/02642060500100783

[19] Perez. De la Rosa, M., S. Texier, G. Berhault, A. Camacho, M.J. Yacaman, A. Mchta, and R.R. Chianelli, "Structural studies of catalytically stabilized model and industrial-supported hydrodesulfurization catalysts," J. Catal. Vol.225, pp.288-299, 2004.

https://doi.org/10.1016/j.jcat.2004.03.039 